\title{
Vinyl Chloride Biodegradation with Methanotrophic AtTaCHed Films
}

\author{
By Yarrow M. Nelson,' and William J. Jewell ${ }^{2}$
}

\begin{abstract}
Methanotrophic degradation of vinyl chloride (VC) is investigated using a laboratory-scale methanotrophic attached-film expanded-bed (MAFEB) bioreactor. This study provides a basis for applying a microbial cometabolizing reaction to practical treatment of toxic chlorinated compounds. The MAFEB reactor was operated at $20^{\circ} \mathrm{C}$ with influent $\mathrm{VC}$ concentrations ranging from 1,800 to $9,600 \mu \mathrm{g} / \mathrm{L}$ and bed hydraulic retention times ranging from 3.7 to $7.6 \mathrm{~h}$. VC effluent concentrations during steady continuous operation ranged from 3 to $140 \mu \mathrm{g} / \mathrm{L}$, with most values less than $26 \mu \mathrm{g} / \mathrm{L}$, resulting in removal efficiencies of $96.3 \%$ to $99.8 \%$. The maximum continuous-flow VC degradation rate observed at $20^{\circ} \mathrm{C}$ was $2.5 \mathrm{mg}$ VC per gram volatile solids (VS) per day $[2.5 \mathrm{mg} \mathrm{VC/(g} \mathrm{VS} \mathrm{d)]} \mathrm{or} 30 \mathrm{mg} \mathrm{VC} \mathrm{per}$ liter expanded bed per day $30 \mathrm{mg} \mathrm{VC} / \mathrm{L}_{e b} \mathrm{~d}$ ), under substrate-limited conditions. During semibatch runs at $35^{\circ} \mathrm{C}$, vinyl chloride degradation rates up to $60 \mathrm{mg} \mathrm{VC} /$ $\left(\mathrm{g}\right.$ VS d) or $1 \mathrm{~g} /\left(\mathrm{L}_{e b} \mathrm{~d}\right)$ were observed. Degradation rates increased with temperature between $20^{\circ} \mathrm{C}$ and $35^{\circ} \mathrm{C}$, approximately doubling every $10^{\circ} \mathrm{C}$. Dissolved methane concentrations above $0.5 \mathrm{mg} / \mathrm{L}$ inhibited VC degradation, with no VC degradation observed with $8 \mathrm{mg} / \mathrm{L}$ dissolved methane. The methane consumed during VC degradation was about $40 \mathrm{~g} \mathrm{CH}_{t} / \mathrm{g}$ VC. Toxic effects were observed after prolonged exposure of the methanotrophic culture to high concentrations of $\mathrm{VC}$.
\end{abstract}

\section{INTRODUCTION}

Chlorinated ethenes, such as tetrachloroethene (PCE), trichloroethene (TCE), dichloroethene (DCE), and chloroethene [vinyl chloride (VC)] are toxic and suspected carcinogens (Craun 1984) and are among the most common ground-water pollutants (Westrick et al. 1984; Love et al. 1982). Biodegradation of TCE, the most common of these compounds, has been studied extensively, while relatively few studies have been conducted on the biodegradation of VC (Chaudhry et al. 1991). Although VC is not expected to enter an aquifer directly, it has been detected at sites contaminated with PCE, TCE, and DCE, presumably as a result of anaerobic reductive dechlorination of these compounds (Parsons et al. 1984, 1985; Milde 1988; Molton 1987). This production of VC is of concern because of the high toxicity and known carcinogenicity of VC ("Ambient" 1980; Maltoni 1977; Lee et al. 1978; Infante 1982). In situ anaerobic remediation processes can also lead to the formation of VC (Vogel and McCarty, 1985).

Vinyl chloride formation must also be considered in the design of aboveground treatment schemes for remediation of contaminated ground-water sites. Ideally, an aboveground anaerobic treatment system for PCE or TCE removal would dechlorinate these compounds to ethene and/or carbon dioxide and chloride ions. However, anaerobic systems have been reported to result in the accumulation of VC as an intermediate (Vogel et al. 1987), particularly when operating at typical ambient groundwater temperatures

'Res. Support Specialist, Dept. of Agric. and Biological Engrg., Cornell Univ., Hollister Hall, Ithaca, NY 14853.

${ }^{2}$ Prof., Dept. of Agric. and Biological Engrg., Cornell Univ., Riley Robb Hall, Ithaca, NY. 
(Freedman and Gossett 1989; Carter 1991). The presence of VC can also cause problems for aboveground remediation with physical processes. The release of $\mathrm{VC}$ during air stripping is becoming unacceptable, and adsorption of VC by activated carbon is limited compared to that of less soluble chlorinated compounds such as PCE and TCE.

We have proposed a two-stage treatment system for complete biodegradation of a range of chlorinated compounds, consisting of an anaerobic first stage followed by an aerobic methanotrophic second stage. The anaerobic stage is expected to dechlorinate highly chlorinated compounds, such as PCE and TCE, while the methanotrophic stage would biodegrade the dechlorination products from the first stage. This hybrid system would utilize the best capabilities of both microbial populations, because anaerobic cultures have been found to degrade highly chlorinated compounds more rapidly than less chlorinated compounds (Vogel et al. 1987; Freedman and Gossett 1989), while methanotrophic cultures have been found to degrade less-chlorinated compounds more rapidly than highly chlorinated compounds (Fogel et al. 1986; Tsien et al. 1989). In fact, methanotrophic degradation of PCE has been reported to be minimal or nonexistent (Fogel et al. 1986; Tsien et al. 1989), and PCE has also been shown to be toxic to methanotrophs (Fennell et al. 1992). Sequential anaerobic/aerobic biodegradation of PCE and TCE has been proposed previously (Fathepure et al. 1987), and the feasibility of applying such a system to in situ remediation has been investigated in a simulated aquifer (Dooley-Danna et al. 1989; Fogel 1990).

Biodegradation of $\mathrm{VC}$ is essential to efficient operation of the two-stage system because of the significant quantities of VC expected to be produced by the anaerobic stage, and because $\mathrm{VC}$ is considered more toxic and carcinogenic than TCE or PCE. Anaerobic cultures have been found to degrade VC by a number of mechanisms (Barrio-Lage et al. 1990; Vogel et al. 1987), but such degradation is slow and inefficient, especially at reduced temperatures (Freedman and Gossett 1989; Chu 1991; Carter 1991). Hartmans et al. (1985) reported that Mycobacterium L1, an aerobic organism, was capable of growing on VC as the sole carbon and energy source. More recently, Davis et al. (1990) reported on aerobic degradation of VC by naturally occurring microorganisms in simulated aquifers. Several studies have briefly examined VC degradation by methanotrophic bacteria (Fogel et al. 1986, 1987; Tsien et al. 1989; Roberts et al. 1989). A VC degradation rate of $14.6 \mathrm{nmol} /(\mathrm{mg} \mathrm{h})[22 \mathrm{mg} /(\mathrm{g} \mathrm{d})]$ was reported by Fogel et al. (1987) using a methanotrophic consortium (temperature not specified). Detailed kinetics of methanotrophic VC degradation remain to be defined, especially for continuous-flow operation at temperatures characteristic of ground water. This work defines the kinetics and feasibility of methanotrophic VC biodegradation in a continuous-flow laboratory-scale reactor.

Experiments were conducted in a methanotrophic attached-film expanded-bed (MAFEB) reactor, which has been described previously (Fennell and Jewell 1992). The primary advantage of an attached-film reactor for this application is the high solids concentration, making operation with short hydraulic retention times possible. It was also hypothesized that the biofilms would enhance the cometabolism reactions, since the primary electron source (dissolved methane) could inhibit VC degradation. Another advantage of this type of reactor is the high effluent quality achieved without secondary settling.

To define the kinetics of VC degradation, a series of continuous-flow and 
semibatch runs were conducted in laboratory-scale MAFEB reactors. Semibatch runs with the same bioreactor were conducted to evaluate the effects of temperature and methane concentration. Toxicity of VC to the methanotrophic culture was also investigated during continuous-flow operation. This work was part of a larger study that has been ongoing since 1988 (Jewell et al. 1990) sponsored by the Gas Research Institute and the U.S. Department of Energy to define processes for aboveground and in situ treatment of contaminated ground waters.

\section{EXPERIMENTAL}

\section{MAFEB Reactor Design}

The MAFEB reactor system (Fig. 1) was similar to MAFEB systems described by Fennell et al. (1992). The $5 \mathrm{~cm}$ diameter expanded-bed volume was 0.4 to $0.8 \mathrm{~L}$, and the total liquid volume in the system was $3.8 \mathrm{~L}$. A 10

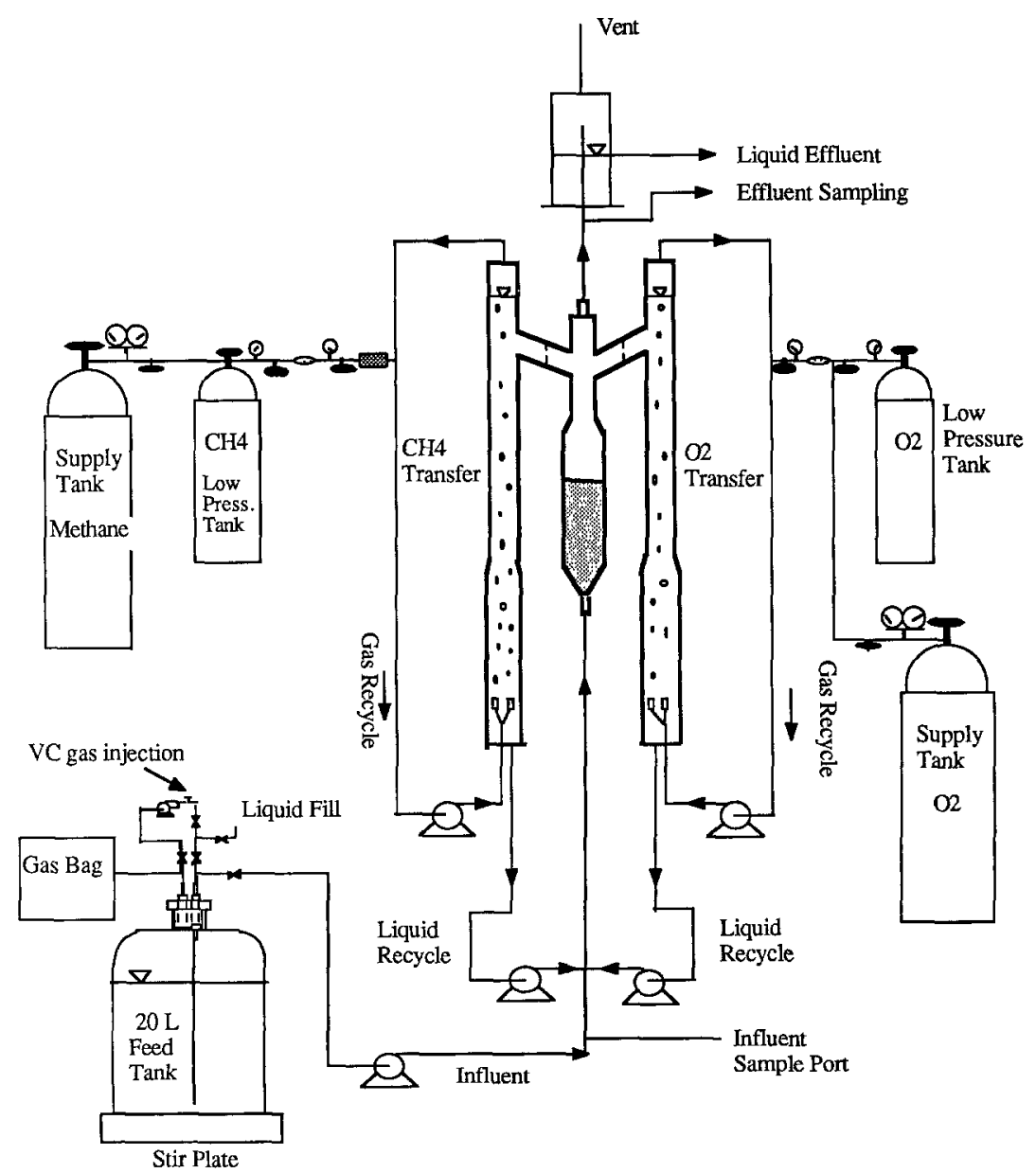

FIG. 1. Schematic of MAFEB Reactor System Used for Methanotrophic VC Degradation Experiments 
to $20 \mathrm{~cm}$ clarifier zone was employed above the bed to allow settling of suspended solids. Liquid recycled above the bed was divided into two separate bubble diffusers where oxygen and methane gas were introduced. The gas exchangers were $100 \mathrm{~cm}$ tall and $3.8 \mathrm{~cm}$ in diameter, expanding to $5 \mathrm{~cm}$ at the bottom to accommodate two diffuser stones. Gases were continuously recycled through both diffusers. Make-up oxygen and methane (Matheson ultra high purity) were supplied to each diffuser from compressed gas cylinders via low-pressure regulators set at $3 \mathrm{kPa}(30 \mathrm{~cm}$ water $)$. Gas was fed from $6.9 \mathrm{~L}$ pressurized tanks that were refilled as needed with oxygen or methane. Gas-use rates were monitored by recording the pressure in these supply cylinders. The reactor system was constructed primarily with glass, stainless steel, polyvinyl chloride, and Teflon components because these materials were found to have minimal reactivity with VC. The reactor system was housed in a temperature-controlled chamber.

\section{Reactor Operation}

Fused diatomaceous earth particles between 300 and $1,000 \mu \mathrm{m}$ in diameter were used as support media for the methanotrophic films in the expanded bed (Eagle-Picher Minerals, Inc., Cincinnati). Particles with mature methanotrophic films were obtained from a larger MAFEB reactor that was operated as a breeder reactor. This breeder reactor was initially inoculated with settled sewage and soil samples from a natural gas outgassing site.

Nutrients were supplied in excess either from secondary sewage effluent or from synthetic nutrient mixtures (Table 1). The mixtures consisted of $\mathrm{NH}_{4} \mathrm{Cl}$, equimolar amounts of $\mathrm{K}_{2} \mathrm{HPO}_{4}$ and $\mathrm{KH}_{2} \mathrm{PO}_{4}$, and yeast extract (BBL Microbiology Systems). Secondary sewage effluent was obtained from a local wastewater-treatment facility.

The reactor was operated with liquid recycle rates of $250 \mathrm{~mL} / \mathrm{min}$ from each diffuser, making the hydraulic retention time in the bed about one minute per pass. The gas recycle rates were $150 \mathrm{~mL} / \mathrm{min}$ and $100 \mathrm{~mL} / \mathrm{min}$ for the oxygen and methane diffusers, respectively. Gas recycle rates were adjusted periodically to control the composition of gases in the diffuser headspaces and to control the dissolved methane concentrations in the reactor. Dissolved gas $\left(\mathrm{CH}_{4}\right.$ and $\left.\mathrm{O}_{2}\right)$ concentrations were measured using a headspace analysis technique with liquid samples. Since copper has been reported to affect methanotrophic yields and MMO enzyme activity (Leak and Dalton 1986; Brusseau et al. 1990), the copper-ion concentrations in the reactor were monitored using inductively coupled plasma spectroscopy.

TABLE 1. Summary of Operating Parameter during VC Continuous-Flow Runs

\begin{tabular}{l|c|c|c|c|c|c}
\hline \multirow{2}{*}{$\begin{array}{c}\text { Condition } \\
\text { (1) }\end{array}$} & \multicolumn{7}{c}{ Run Number } \\
\cline { 2 - 7 } & 1 & 2 & 3 & 4 & 5 & 6 \\
& $(2)$ & $(3)$ & $(4)$ & $(5)$ & $(6)$ & $(7)$ \\
\hline Feed rate (L/day) & $1.5-3.0$ & 3.0 & 1.9 & 2.0 & 2.6 & $0-3$ \\
Expanded-bed volume (L) & 0.46 & 0.6 & 0.6 & 0.6 & 0.6 & 0.5 \\
HRT in expanded bed (h) & $3.7-7.4$ & 4.8 & 7.6 & 7.2 & 5.5 & 4.0 \\
Influent VC concentration (mg/L) & 8.9 & 2.9 & 3.0 & 1.5 & 2.0 & $4-8$ \\
VC loading rate (mg VC/L d $_{\text {eb }}$ d) & $29-58$ & 14.5 & 9.5 & 5.0 & 8.7 & $0-48$ \\
Nutrient concentrations in Feed: & - & - & - & - & - & - \\
Source of feed & Synthetic & Synthetic & Sewage & Sewage & Sewage & Synthetic \\
Ammonia (mg N/L) & 44 & 19 & 14 & 18 & 17 & 40 \\
Phosphate (mg P/L) & 3.4 & 2.8 & 1.0 & 1.1 & 0.9 & 4 \\
Yeast extract (mg/L) & 5 & 2.5 & 0 & 0 & 0 & 2.5 \\
Duration of experiment (days) & 22 & 10 & 8 & 8 & 7 & 27 \\
Temperature ( $\left.{ }^{\circ} \mathrm{C}\right)$ & 20 & 20 & 20 & 20 & 20 & 19 \\
\hline \hline
\end{tabular}




\section{Continuous-Flow Runs}

Six continuous-flow runs with VC were operated at $20^{\circ} \mathrm{C} \pm 1^{\circ} \mathrm{C}$ (Table 1). VC was analyzed daily by headspace gas chromatographic analysis of influent and effluent liquid samples. Influent samples were collected from the feed line upstream from the feed pump, and effluent samples were collected from a sample port in the liquid recycle line. Dissolved methane and oxygen were measured by a similar technique for samples collected above and below the expanded bed. Feed rates were varied in response to observed VC toxicity effects. As methane inhibition became evident, the gas recycle rates were adjusted to control the dissolved methane concentration in the reactor.

\section{Semibatch Runs}

Semibatch experiments were conducted with the same apparatus and attached film biomass as used for the continuous-flow runs. VC was added to the reactor system at the beginning of each run, while oxygen and methane were supplied continuously. At the beginning of the tests, pure VC gas (Alphagaz Specialty Gas Products) was injected into the methane-gas recycle line. Just prior to injecting VC to start the semibatch runs, $100 \mathrm{~mL}$. of nutrient stock solution ( $800 \mathrm{mgN} / \mathrm{L}$ and $80 \mathrm{mgP} / \mathrm{L}$.) was pumped into the reactor. Liquid samples were taken from the liquid recycle line below the expanded bed (Fig. 1), starting about 5 min after VC injection.

Semibatch runs for the methane inhibition study were conducted at $20^{\circ} \mathrm{C}$ and operated with a $\mathrm{pH}$ between 5 and 6 . These runs were initiated with 5 $\mathrm{mL}$ of $\mathrm{VC}$ gas that resulted in initial aqueous $\mathrm{VC}$ concentrations of about $1.5 \mathrm{mg} / \mathrm{L}$. The expanded-bed volume varied from 0.35 to $0.40 \mathrm{~L}$, and the total biomass content of the reactor varied from 6.2 to $8.2 \mathrm{~g}$ volatile solids (VS). Total biomass content at the time of each run was estimated from initial and final measurements and from the amount of methane used up to the time the semibatch run was initiated. Gas recycle rates were adjusted to control the dissolved methane concentration in the reactor.

Temperature effects were examined between $20^{\circ} \mathrm{C}$ and $35^{\circ} \mathrm{C}$. These runs were initiated with $15 \mathrm{~mL}$ of VC gas injected into the reactor, which resulted in initial VC concentrations of 3 to $5 \mathrm{mg} / \mathrm{L}$. Reactor effluent $\mathrm{pH}$ was similar for all of these semibatch runs (5.3 to 5.5). Prior to and in between each of these semibatch runs, the MAFEB reactor was operated in continuousflow mode without VC to maintain growth of the methanotrophic culture. The methanotrophic culture was allowed to acclimate to each new temperature by operating the reactor in continuous-flow mode for one to two weeks (10 to 15 total system hydraulic retention times) prior to each semibatch run.

\section{Reactor Control Tests}

The integrity of the reactor system with respect to VC loss was evaluated using semibatch and continuous-flow reactor control tests. These tests were conducted with a clean reactor system that was filled with distilled water and purged with nitrogen. Semibatch reactor control tests were initiated by injecting $15 \mathrm{~mL}$ of VC gas via the methane gas recycle line, which resulted in an initial aqueous $\mathrm{VC}$ concentration of $6.5 \mathrm{mg} / \mathrm{L}$. During the semibatch control runs, all recycle pumps were operated at the same rates as in actual semibatch runs. After $100 \mathrm{~h}$ of operation, the VC concentration measured in the reactor remained within $0.5 \mathrm{mg} / \mathrm{L}$ of the initial value. Continuousflow reactor control tests were operated by flowing a $10 \mathrm{mg} / \mathrm{L}$ solution of 
$\mathrm{VC}$ through the reactor system at a rate of $3 \mathrm{~L} / \mathrm{d}$. Liquid samples were collected from the reactor influent and effluent ports twice daily for analysis. This test resulted in less than $6 \%$ variation between influent and effluent VC concentrations for six days of operation.

The semibatch and continuous-flow control tests confirmed that the reactor system itself does not adsorb or leak VC. Adsorption of VC by the bed material was investigated during a semibatch run in which biodegradation of $\mathrm{VC}$ was inhibited with high dissolved methane concentrations. Under these conditions, little or no loss of $\mathrm{VC}$ was observed, indicating that $\mathrm{VC}$ was not lost due to adsorption by the bed. These results rule-out any short-term VC adsorption or loss during the semibatch tests. It can be concluded that all reductions of VC during the experiments in the MAFEB reactor are attributable only to biodegradation.

\section{Analytical}

$\mathrm{VC}$ concentrations in gas samples from the MAFEB reactor headspaces were determined by direct gas chromatography of the samples. VC concentrations in liquid samples were determined by analyzing the gas headspace of samples in $5 \mathrm{~mL}$ reaction vials (Supelco, Inc., Bellefonte, $\mathrm{Pa}$.). VC in the headspace of these samples was analyzed with an HP 5890 gas chromatograph (GC) (Hewlett Packard) equipped with a flame ionization

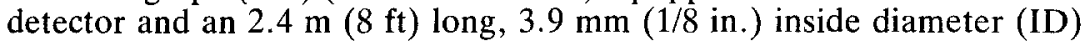
stainless-steel column packed with SP-1000 on 60/80 Carbopak B (Supelco). Helium was used as the carrier gas at a flow rate of $35 \mathrm{~mL} / \mathrm{min}$ and a pressure of $400 \mathrm{kPa}(60 \mathrm{psi})$. The column temperature was $160^{\circ} \mathrm{C}$, which resulted in $\mathrm{VC}$ retention times of $0.65 \mathrm{~min}$. The total amount of $\mathrm{VC}$ in the sample was determined using Henry's constants published by Gossett (1987).

Gas concentrations of $\mathrm{O}_{2}, \mathrm{CH}_{4}, \mathrm{CO}_{2}$, and $\mathrm{N}_{2}$ were determined by gas chromatography using a Gow Mac Series $580 \mathrm{GC}$ with a thermal-conductivity detector. The chromatograph was equipped with two $1.7 \mathrm{~m}$ steel columns $(0.6 \mathrm{~cm}$ ID). The columns were packed with 60/80 mesh Poropak $\mathrm{Q}$ (Supelco) for $\mathrm{CH}_{4}$ and $\mathrm{CO}_{2}$ measurement and with 60/80 mesh Molecular Sieve 5A (Supelco) for $\mathrm{O}_{2}$ and $\mathrm{N}_{2}$ measurement.

Dissolved methane concentrations were measured using a headspace GC technique. Headspaces of sealed liquid samples were analyzed for methane using the Gow Mac GC equipped as described previously. Liquid samples were collected with a glass syringe from the recycle line just below the expanded bed, or from an effluent port above the expanded bed. Since the retention time of liquid in the bed per pass was usually only $1 \mathrm{~min}$, the reactor approached completely mixed conditions. However, rapid uptake of methane in the bed caused a differential between the influent and effluent dissolved methane concentration averaging about $0.5 \mathrm{mg} / \mathrm{L}$.

Total suspended and volatile suspended solids of the reactor liquid were determined by methods 209C and 209D, respectively, of Standard Methods, 16th Ed. (1985). This procedure was also used to analyze solids removed from the reactor during cleaning to assay the volatile solids content of the wall growth and sludge in the reactor. Volatile solids attached and entrapped in the expanded bed were determined by a technique described by Clarkson (1986), in which samples of the bed were weighed after drying and after ashing at $550^{\circ} \mathrm{C}$. 


\section{RESULTS}

\section{General Reactor Operation}

Well-defined operation of the methanotrophic attached-film expandedbed reactor was sustained for a period of about 2 years, during which time these experiments with vinyl chloride were conducted. The MAFEB system operated with similar growth characteristics and gas-use rates as those previously observed for this type of reactor system, as shown in Table 2 and Fennell and Jewell (1992). The total quantity of attached film was limited to one third to one 10th of the maximum potential, which appeared to be around $50 \mathrm{~g} \mathrm{VS} / \mathrm{L}$ in earlier long-term tests (Fennell and Jewell 1992). Growth rates and yields varied significantly between runs due to differences in operating conditions. Observed yields were similar to those reported for methanotrophs in the literature (Vary and Johnson 1967), except during runs CF-1 and CF-6 during which high VC concentrations may have limited growth. Another factor affecting growth rates was the rate of methane gas recycle, which was reduced during runs $\mathrm{CF}-4$ through $\mathrm{CF}-6$ to avoid suspected methane inhibition of $\mathrm{VC}$ degradation.

Growth on the walls of the reactor and suspended in the diffusers accounted for $10 \%$ to $20 \%$ of the total growth, and the remainder of the growth occurred in the expanded bed. The reactor was operated without addition of alkalinity to the feed, and therefore $\mathrm{CO}_{2}$ evolved by the methanotrophs resulted in a low operating pH of between 5.5 and 6.0 (Table 2). In contrast to studies that indicate an optimum $\mathrm{pH}$ for growth near neutral (Vary and Johnson 1967), our cultures appeared to grow more rapidly at a pH near 6.0.

\section{Continuous-Flow VC Degradation}

The MAFEB reactor was operated for six continuous-flow runs with influent VC concentrations ranging from 1,000 to $10,000 \mu \mathrm{g} / \mathrm{L}$ and expandedbed hydraulic retention times ranging from 3.7 to $7.6 \mathrm{~h}$ (Table 1 ). The continuous-flow runs with relatively low VC loading rates $(2-5)$ proceeded with rapid and consistent VC degradation (Fig. 2). Average VC removal

TABLE 2. Summary of Results of Solids Analyses, Growth Rates, Gas-Use and Microbial Yields During Continuous-Flow Tests Under Steady Operating Parameter

\begin{tabular}{|c|c|c|c|c|c|c|}
\hline \multirow[b]{2}{*}{$\begin{array}{l}\text { Condition } \\
\text { (1) }\end{array}$} & \multicolumn{6}{|c|}{ Run Number } \\
\hline & $\begin{array}{c}1 \\
(2)\end{array}$ & $\begin{array}{c}2 \\
(3) \\
\end{array}$ & $\begin{array}{c}3 \\
(4)\end{array}$ & $\begin{array}{c}4 \\
(5)\end{array}$ & $\begin{array}{r}5 \\
(6) \\
\end{array}$ & $\begin{array}{c}6 \\
(7)\end{array}$ \\
\hline Total Initial Seed (g VS) & 2.7 & 3.5 & 2.0 & 3.7 & 2.9 & 3.1 \\
\hline \multicolumn{7}{|l|}{ Final Biomass: } \\
\hline Bed Conc., attached (g VS/L $\mathrm{L}_{e b}$ ) & 9.3 & 14 & 7.6 & 5.8 & 5.8 & 5.2 \\
\hline Bed, attached (g VS) & 4.3 & 8.6 & 4.6 & 3.5 & 3.5 & 2.6 \\
\hline Bed, Entrapped (g VS) & 1.4 & 0.79 & 0.55 & 0.83 & 0.35 & 0.20 \\
\hline Wall Growth/Sludge (g VS) & 0.66 & 0.67 & 0.88 & 1.10 & 0.27 & 0.86 \\
\hline Average Biomass in System (g VS) & 5.8 & 6.7 & 4.0 & 4.5 & 4.1 & 3.4 \\
\hline Suspended Solids (mg VSS/L) & 13 & 11 & 30 & 30 & 7 & 7 \\
\hline Total SS Wasted to Effluent (g VSS) & 0.46 & 0.33 & 0.53 & 0.43 & 0.11 & 0.30 \\
\hline Daily Growth Rate (g VS/d) & 0.05 & 0.62 & 0.66 & 0.30 & 0.22 & 0.04 \\
\hline Avg. Observed Yield (g VS/g COD) & 0.03 & 0.13 & 0.15 & 0.07 & 0.08 & 0.03 \\
\hline Methane use average $(\mathrm{L} / \mathrm{d})$ & 0.59 & 1.7 & 1.6 & 1.2 & 0.9 & 0.4 \\
\hline Oxygen use average $(\mathrm{L} / \mathrm{d})$ & 0.69 & 2.5 & 2.5 & 1.9 & 1.6 & 0.9 \\
\hline Oxygen/Methane Ratio (L/L) & 1.2 & 1.5 & 1.6 & 1.6 & 1.7 & 1.5 \\
\hline Avg. Effluent pH & $5.5-6.8$ & 5.5 & 5.8 & 5.9 & 6.1 & 5.8 \\
\hline
\end{tabular}



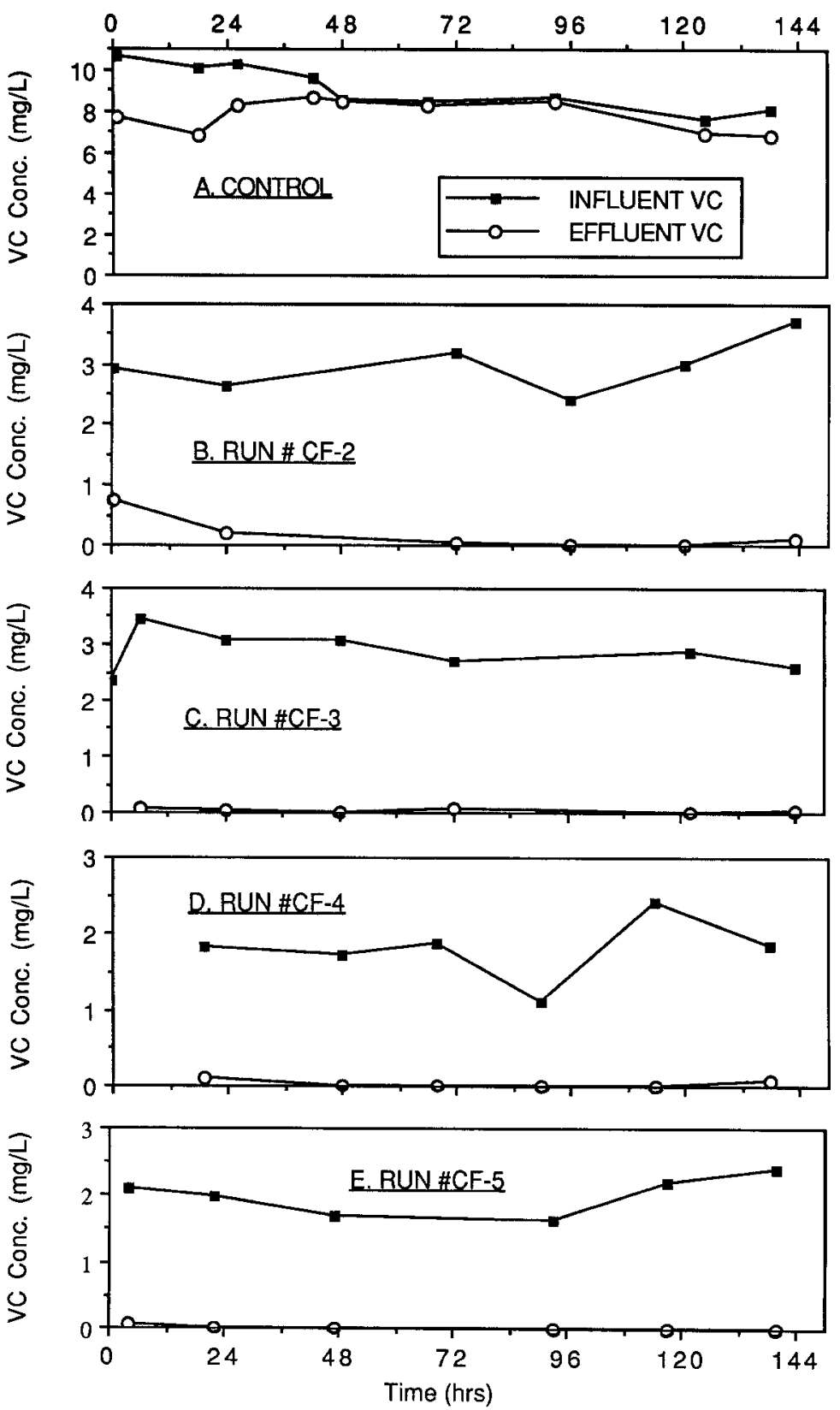

FIG. 2. Influent and Effluent VC Concentrations during Continuous-Flow Runs in the MAFEB Reactor without Observed VC Toxicity 
TABLE 3. Summary of Vinyl Degradation Steady Parameter of VC ContinuousFlow Runs

\begin{tabular}{|c|c|c|c|c|c|c|}
\hline \multirow[b]{2}{*}{$\begin{array}{l}\text { Condition } \\
\text { (1) }\end{array}$} & \multicolumn{6}{|c|}{ Run Number } \\
\hline & $\begin{array}{c}1 \\
(2)\end{array}$ & $\begin{array}{c}2 \\
(3)\end{array}$ & $\begin{array}{l}3 \\
(4)\end{array}$ & $\begin{array}{c}4 \\
(5)\end{array}$ & $\begin{array}{c}5 \\
(6)\end{array}$ & $\begin{array}{l}6 \\
(7)\end{array}$ \\
\hline $\begin{array}{l}\text { Average influent } \mathrm{VC} \text { con- } \\
\text { centration }(\mu \mathrm{g} / \mathrm{L})^{\mathrm{b}}\end{array}$ & $8,900(900)$ & $2,900(800)$ & $2,900(300)$ & $1,800(500)$ & $2,000(300)$ & $3,800(400)$ \\
\hline $\begin{array}{l}\text { Average effluent VC con- } \\
\text { centration }(\mu \mathrm{g} / \mathrm{L})^{\mathrm{b}}\end{array}$ & $26(8)$ & $13(7)$ & $13(9)$ & $5(2)$ & $3(0.8)$ & $140(70)$ \\
\hline Removal Efficiency (\%) & 99.7 & 99.6 & 99.6 & 99.8 & 99.8 & 96.3 \\
\hline $\begin{array}{l}\text { Average dissolved meth- } \\
\text { ane concentration } \\
(\mathrm{mg} / \mathrm{L})^{c}\end{array}$ & 0.2 & 0.3 & 0.2 & $<0.01$ & $<0.01$ & 0.1 \\
\hline $\begin{array}{l}\text { VC Degradation rates: } \\
\text { Biomass basis (mg VC/g }\end{array}$ & - & - & - & - & - & - \\
\hline $\begin{array}{l}\text { VS-day) } \\
\text { Exp. Bed basis (mg VCl }\end{array}$ & 1.7 & 1.2 & 1.4 & 0.96 & 1.3 & 2.5 \\
\hline $\begin{array}{l}\mathrm{L}_{e b} \text {-day) } \\
\text { Methane Requirement (g }\end{array}$ & 20 & 14 & 9.0 & 7.6 & 10 & 17 \\
\hline $\mathrm{CH}_{4} / \mathrm{g} \mathrm{VC}^{1}$ & 43 & 140 & 200 & 240 & 130 & 39 \\
\hline
\end{tabular}

${ }^{\mathrm{a}}$ For the runs with VC toxicity, data are summarized for periods of operation for which this effect was minimized or eliminated.

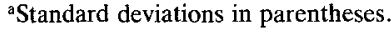

'During period for which VC degradation kinetics were determined.

efficiencies greater than $99.6 \%$ were observed in all four of these experimental runs (Table 3). The continuous-flow control run (without methanotrophs) exhibited less than $6 \%$ loss of VC concentration under these conditions (Fig. 2). Toxicity of VC was suspected to have limited the operation of the MAFEB system during parts of the continuous-flow runs with higher VC loading rates (runs 1 and 6). High concentrations of dissolved methane also appear to have inhibited VC degradation during some of the runs. These inhibitory effects are discussed later herein. After minimizing VC toxicity and methane inhibition, the fifth continuous-flow run resulted in the most successful operation of the system. During this reactor run, with an expanded-bed HRT of $5.5 \mathrm{~h}$, the aqueous VC concentration was consistently reduced from about $2,000 \mu \mathrm{g} / \mathrm{L}$ to $2-3 \mu \mathrm{g} / \mathrm{L}$ throughout the run (Fig. 2). The VC removal efficiency during this run was $99.8 \%$, and the average $\mathrm{VC}$ degradation rate was $10 \mathrm{mg} \mathrm{VC}\left(\mathrm{L}_{e b} \mathrm{~d}\right)$ or $1.3 \mathrm{mg} \mathrm{VC} /(\mathrm{g} \mathrm{VS} \mathrm{d})$ (Table 3), where the subscript $e b$ equals expanded bed.

$\mathrm{VC}$ degradation rates and removal efficiencies were calculated for periods of steady operating conditions during each of the six continuous-flow runs in the MAFEB reactor (Table 3). VC degradation rates were observed to increase with increasing VC loading rate, and high degradation rates corresponded to high effluent VC concentrations (Fig. 3). VC degradation rates, expressed in terms of reactor expanded-bed volume, ranged from 7.6 to $20 \mathrm{mg} \mathrm{VC} /\left(\mathrm{L}_{e b} \mathrm{~d}\right)$. On a biomass basis, the observed degradation rates varied from 0.96 to $2.5 \mathrm{mg} \mathrm{VC} /(\mathrm{g}$ VS d). The operating effluent $\mathrm{VC}$ concentrations over which these rates were observed ranged from 3 to 140 $\mu \mathrm{g} / \mathrm{L}$ (Table 3). All degradation rates were observed for low VC concentrations, under substrate-limited conditions, except for the runs for which VC toxicity effects were observed. Continuous-flow kinetics could not be determined for higher $\mathrm{VC}$ concentrations because of the apparent VC toxicity. This effect is discussed later.

The methane requirement for $\mathrm{VC}$ degradation during the continuous- 


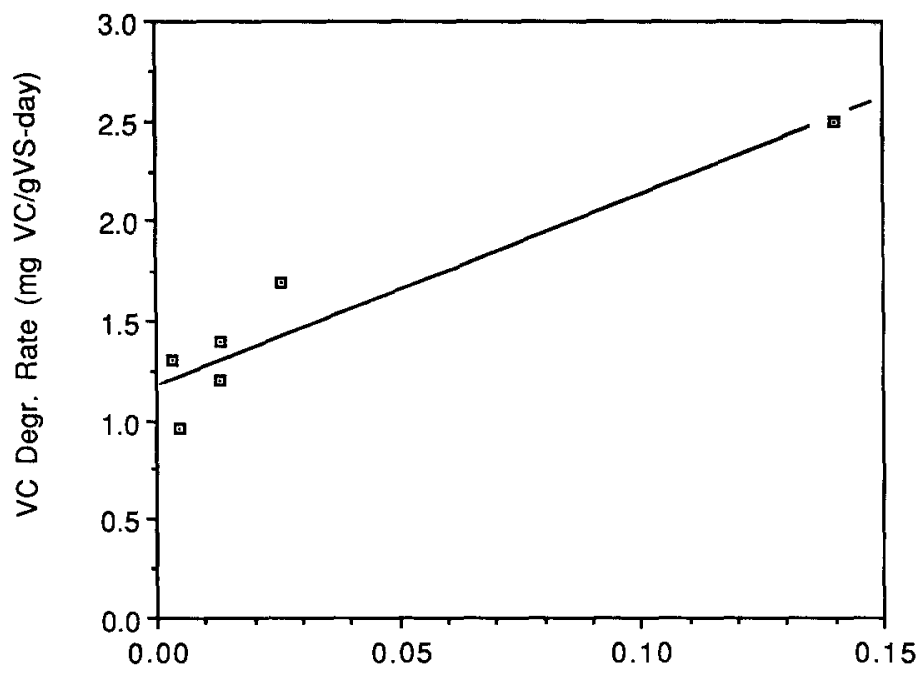

Effluent VC Concentration (mg/L)

FIG. 3. VC Degradation Rates as Function of Effluent VC Concentration during Continuous-Flow Runs in MAFEB Reactor

flow tests varied from 40 to $240 \mathrm{~g} \mathrm{CH}_{4} / \mathrm{g} \mathrm{VC}$ (Table 3 ). Methane consumption was lowest during the two continuous-flow runs with the highest VC loading rates and effluent VC concentrations ( 1 and 6 ). The low methane consumption during these runs may have been related to suspected VC toxicity that would have lowered methane uptake rates. Methane consumption was the greatest during the runs with the lowest VC loading rates (Table 3 ). Since methanotrophic VC degradation is thought to be a cometabolic process, VC degradation might be expected to be related to methane consumption by a fixed cometabolism ratio. However, in the present experiments, no attempt was made to optimize (minimize) methane consumption, and the observed methane-use rates were probably much higher than any theoretical cometabolism ratio. Since VC degradation is possible in the absence of methane, it may be possible to optimize methane consumption to lower levels than those reported here.

\section{VC Toxicity/Inhibition}

Sustained aqueous VC concentrations between 5 and $10 \mathrm{mg} / \mathrm{L}$ were found to inhibit both the growth of the methanotrophic culture and its ability to oxidize VC. This inhibition was observed only in continuous-flow runs 1 and 6, during which high $\mathrm{VC}$ loading rates were employed and high effluent $\mathrm{VC}$ concentrations were sustained during part of the run. Influent and effluent VC concentrations during these two runs are shown in Fig. 4. VC toxicity or inhibition appeared to result in a poor $\mathrm{VC}$ removal efficiency during the beginning of each of these runs. In both cases, a reduction of the VC loading rate alleviated the problem, and $\mathrm{VC}$ removal efficiencies improved toward the end of the experiments (Fig. 4). Inhibition of the methanotrophs during these two runs was also characterized by a reduction in methane and oxygen use and an increase in effluent $\mathrm{pH}$ due to decreased 

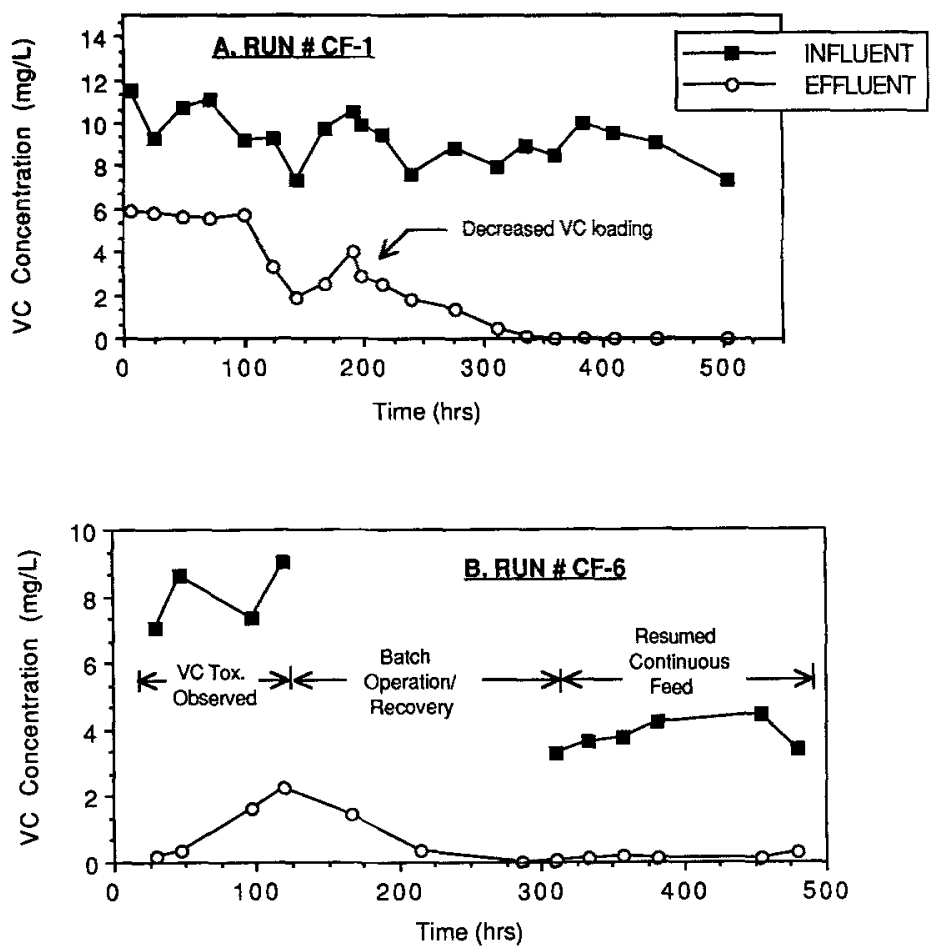

FIG. 4. Influent and Effluent VC Concentrations during Continuous-Flow Runs with Suspected VC Toxicity

$\mathrm{CO}_{2}$ production. Methane use rates decreased from about 2-4 $\mathrm{L} /\left(\mathrm{L}_{e b} \mathrm{~d}\right)$ at low VC operating concentrations to less than $0.6 \mathrm{~L} /\left(\mathrm{L}_{e b} \mathrm{~d}\right)$ with a $\mathrm{VC}$ operating concentration of $5 \mathrm{mg} \mathrm{VC/L}$. VC inhibition reduced the observed daily growth rates by $80-90 \%$ and reduced observed yields by a factor of three to five (Table 2, compare runs 2-5 with runs 1 and 6). The inhibitory effect of VC was self-perpetuating because the reduction in VC degradation rates concomitantly resulted in a further increase in $\mathrm{VC}$ concentration and VC inhibition. The observed inhibition and/or toxicity may have been caused by toxic intermediates formed during $\mathrm{VC}$ degradation. Other researchers report that toxic epoxide intermediates formed during methanotrophic trichloroethene degradation were responsible for loss of methanotrophic activity (Alvarez-Cohen and McCarty 1991).

Recovery of the MAFEB system from VC inhibition was observed by turning off the feed to the reactor after a period of $\mathrm{VC}$ inhibition during run 6 . The reactor was then operated in semibatch mode for a period of 10 days, during which time gas use gradually increased and the VC concentration gradually decreased. The VC concentration in the reactor was eventually reduced to $1 \mu \mathrm{g} / \mathrm{L}$ after 10 days (Fig. 4). This test demonstrated the ability of the culture to recover from the VC-induced stress, but the recovery was slow. This long recovery period indicates that the effect of $\mathrm{VC}$ may have been more than enzyme site saturation and may have involved some toxic effects. 


\section{Semibatch VC Degradation Kinetics}

Short-term semibatch tests were conducted to further define VC degradation kinetics at higher $\mathrm{VC}$ concentrations and to investigate temperature effects and methane inhibition. Each semibatch test was conducted after a period of continuous operation during which steady growth, gas-uptake rates, and $\mathrm{pH}$ were maintained.

The effect of temperature on VC degradation rates was investigated by conducting semibatch runs in the MAFEB reactor at $35^{\circ} \mathrm{C}, 25^{\circ} \mathrm{C}$, and $21^{\circ} \mathrm{C}$ (Table 4). Dissolved methane was maintained at low concentrations during these runs, usually less than $1 \mathrm{mg} / \mathrm{L}$. During semibatch runs at all three temperatures, the measured aqueous VC concentration in the MAFEB reactor decreased exponentially from its initial value to near the detection limit (Fig. 5). At $35^{\circ} \mathrm{C}$, the VC concentration decreased from an initial value of $5,400 \mu \mathrm{g} / \mathrm{L}$ to below detection limits $(<5 \mu \mathrm{g} / \mathrm{L})$ after $8 \mathrm{~h}$. During the run at $25^{\circ} \mathrm{C}$, the VC concentration decreased from $6,000 \mu \mathrm{g} / \mathrm{L}$ to $10 \mu \mathrm{g} / \mathrm{L}$ in 24 h. At $21^{\circ} \mathrm{C}$ the $\mathrm{VC}$ concentration decreased from an initial concentration of $6,000 \mu \mathrm{g} / \mathrm{L}$ to $130 \mu \mathrm{g} / \mathrm{L}$ in $14 \mathrm{~h}$, and after $24 \mathrm{~h}, \mathrm{VC}$ was undetectable in

TABLE 4. VC Degradation Rates and MAFEB Operating Parameter during Batch runs at $21^{\circ} \mathrm{C}, 25^{\circ} \mathrm{C}$, and $35^{\circ} \mathrm{C}$

\begin{tabular}{|c|c|c|c|}
\hline \multirow[b]{2}{*}{$\begin{array}{l}\text { Condition } \\
\text { (1) }\end{array}$} & \multicolumn{3}{|c|}{ Operating Temperature } \\
\hline & $\begin{array}{c}21^{\circ} \mathrm{C} \\
(2)\end{array}$ & $\begin{array}{c}25^{\circ} \mathrm{C} \\
(3)\end{array}$ & $\begin{array}{c}35^{\circ} \mathrm{C} \\
(4)\end{array}$ \\
\hline Reactor effluent $\mathrm{pH}$ & 5.30 & 5.30 & 5.5 \\
\hline Expanded-bed volume $\left(\mathrm{L}_{c h}\right)$ & 0.40 & 0.35 & 0.38 \\
\hline Total biomass content (g VS) & 8.2 & 8.2 & 6.2 \\
\hline Initial VC concentration $(\mathrm{mg} / \mathrm{L})$ & 5.7 & 3.4 & 4.3 \\
\hline Initial VC degradation rate & - & - & - \\
\hline (mg VC/g VD d) & 25 & 31 & 63 \\
\hline (mg VC/L $\left.\mathrm{L}_{e h}-\mathrm{d}\right)$ & 530 & 680 & 970 \\
\hline
\end{tabular}

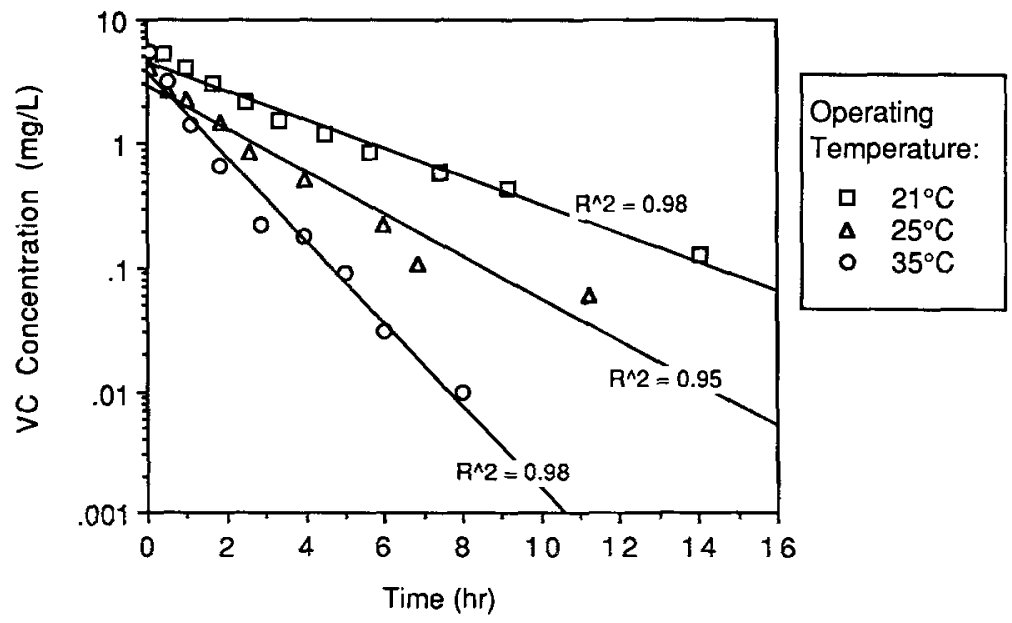

FIG. 5. Semilog Plots of VC Concentration versus Time for Semibatch Runs at Three Operating Temperatures 
the reactor effluent. The linear relationship between the $\log$ of the $\mathrm{VC}$ concentration and time indicates that $\mathrm{VC}$ degradation during these semibatch runs followed a first-order relationship over this concentration range.

Initial degradation rates during each run are listed in Table 4 , both on a biomass basis and on the basis of expanded-bed volume. The highest VC degradation rate observed in these semibatch experiments was $63 \mathrm{mg} \mathrm{VCl}$ (g VS d), which was observed at $35^{\circ} \mathrm{C}$. At $21^{\circ} \mathrm{C}$, the maximum VC degradation rate was $25 \mathrm{mg} \mathrm{VC/(g} \mathrm{VS} \mathrm{d).} \mathrm{A} \mathrm{linear} \mathrm{relationship} \mathrm{between} \mathrm{degra-}$ dation rate and concentration was observed at both temperatures over this concentration range (Fig. 6). The slope of the rate versus concentration plot for the $35^{\circ} \mathrm{C}$ data are about three times greater than that at $21^{\circ} \mathrm{C}$, indicating a threefold increase in degradation rate with this $14^{\circ} \mathrm{C}$ degree increase in temperature. This effect of temperature roughly corresponds to a doubling of the degradation rate for every $10^{\circ} \mathrm{C}$ increase in temperature.

\section{METHANE INHIBITION}

Methane inhibition was suspected to be limiting $\mathrm{VC}$ degradation during the continuous-flow runs because high dissolved methane concentrations correlated with decreased VC degradation rates. In all of the continuousflow runs, the most efficient VC degradation was observed with low dissolved methane concentrations, while the least efficient $\mathrm{VC}$ degradation was observed with high dissolved methane concentrations. Degradation of VC to concentrations below $10 \mu \mathrm{g} / \mathrm{L}$ was only observed when the dissolved methane concentration above the bed was below about $0.5 \mathrm{mg} / \mathrm{L}$. It appears that methane inhibits the ability of the MMO enzyme to oxidize VC. Such inhibition has been recently reported for methanotrophic TCE degradation (Henry and Grbic-Galic 1991).

Methane inhibition was examined further by conducting semibatch runs in the MAFEB reactor with a series of controlled dissolved methane concentrations. Stable dissolved methane concentrations were maintained in

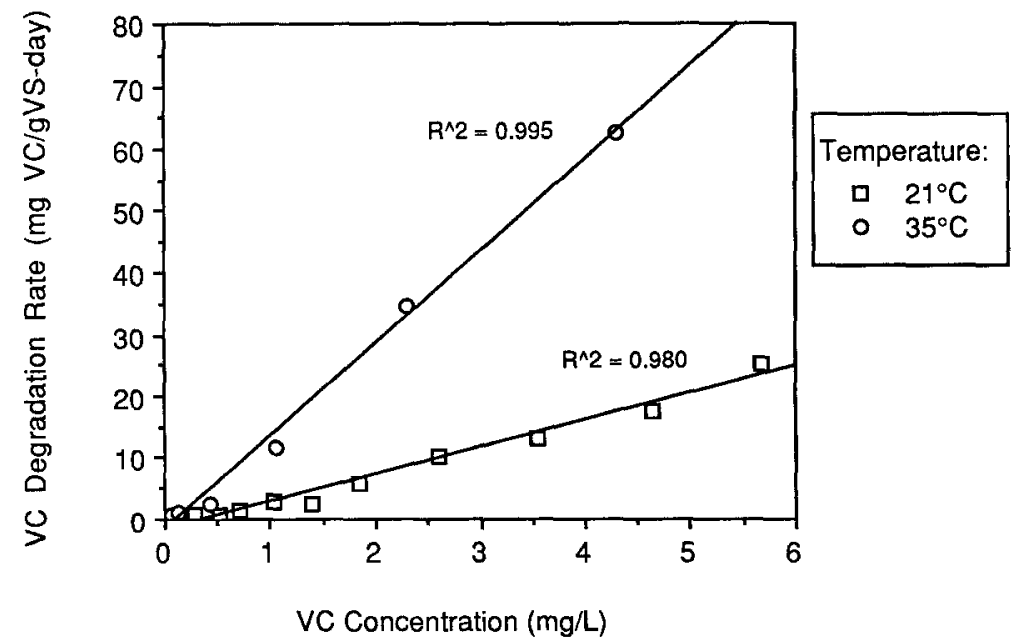

FIG. 6. Effect of Temperature on VC Degradation Rates during MAFEB Semibatch Runs 


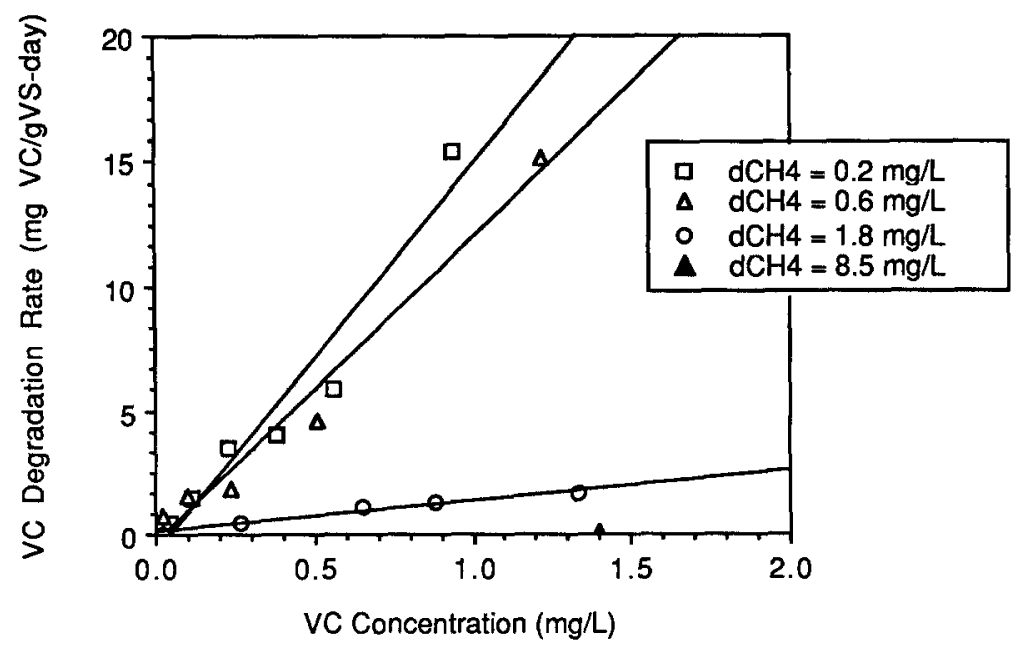

FIG. 7. Effect of Dissolved Methane Concentration (above Expanded Bed) on Rates of Vinyl Chloride Degradation

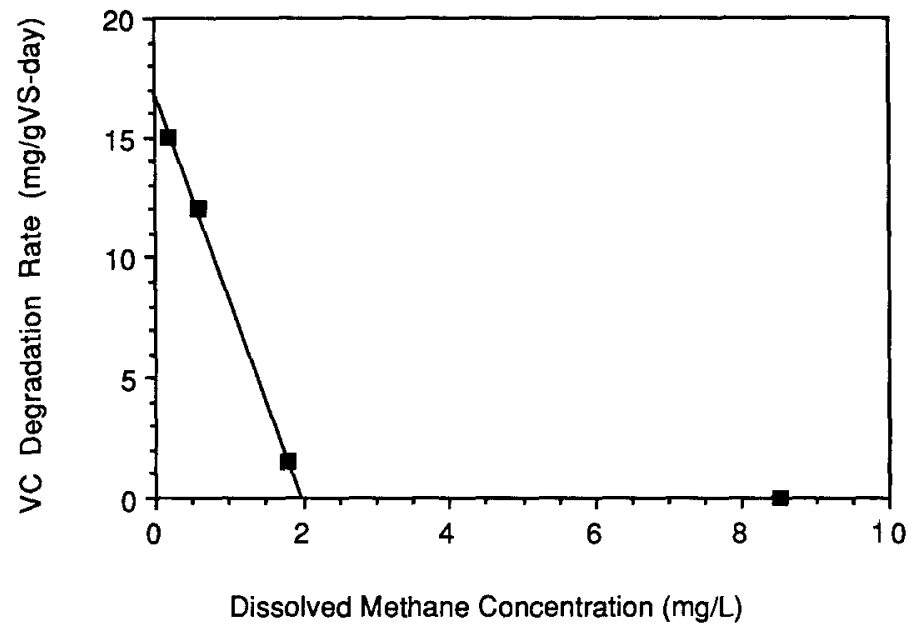

FIG. 8. Effect of Dissolved Methane on VC Degradation Rate at an Operating Concentration of $1 \mathrm{mg} \mathrm{VC/L}$

four semibatch runs by adjusting gas recycle rates, resulting in dissolved methane concentrations above the expanded bed ranging from 0.2 to 8.5 $\mathrm{mg} / \mathrm{L}$. The observed VC degradation rates were approximately first order with VC concentration, and were strongly influenced by dissolved methane in the reactor (Fig. 7). Rates up to $15 \mathrm{mg}$ VC (g VS d) were observed with low dissolved methane concentrations, while little or no VC degradation was observed when the dissolved methane concentration was increased to $8.5 \mathrm{mg} / \mathrm{L}$. Methane inhibition of VC degradation can be summarized by comparing $\mathrm{VC}$ degradation rates measured at a time during each semibatch run when the operating $\mathrm{VC}$ concentration was $1 \mathrm{mg} / \mathrm{L}$. These rates are 
plotted as a function of dissolved methane concentration in Fig. 8. VC degradation decreased linearly with increasing dissolved methane concentration up to a concentration of about $2 \mathrm{mg} \mathrm{CH} / \mathrm{L}$. Above $2 \mathrm{mg} \mathrm{CH}_{4} / \mathrm{L}$, $\mathrm{VC}$ degradation was extremely inhibited (Fig. 8).

\section{CONCLUSIONS}

These experiments have demonstrated the feasibility methanotrophic VC degradation in attached-film expanded-bed bioreactors on a laboratory scale. Under optimized conditions (low dissolved methane concentration and low VC concentration), $\mathrm{VC}$ removal efficiencies as high as $99.8 \%$ were observed in the MAFEB system on a continuous-flow basis. Vinyl chloride concentations were reduced from $2,000 \mu \mathrm{g} / \mathrm{L}$ to $3 \mu \mathrm{g} / \mathrm{L}$ with a hydraulic retention time in the bed of $5.5 \mathrm{~h}$. The methane requirement for $\mathrm{VC}$ degradation ranged from 40 to $240 \mathrm{~g} \mathrm{CH}_{4} / \mathrm{g} \mathrm{VC}$, with the higher values associated with low VC loading rates. Vinyl chloride degradation rates during continuousflow operation varied from 10 to $20 \mathrm{mg} \mathrm{VC} /\left(\mathrm{L}_{e b} \mathrm{~d}\right)$ for operating $\mathrm{VC}$ concentrations between 1 and $100 \mu \mathrm{g} \mathrm{VC} / \mathrm{L}$.

Much higher VC degradation rates were observed during batch runs than during continuous-flow runs because the batch runs were conducted with much higher VC concentrations than the continuous-flow runs. The VC concentration employed in continuous-flow experiments was limited because high VC loading rates apparently resulted in toxic effects. The continuousflow runs were substrate limited with respect to $\mathrm{VC}$, and they were conducted with extremely low effluent VC concentrations, often as low as 3 $\mu \mathrm{g} / \mathrm{L}$. Under these conditions, $\mathrm{VC}$ degradation rates of about $1 \mathrm{mg} \mathrm{VC} /(\mathrm{g}$ VS d) were observed. During semibatch runs, VC degradation rates were observed to follow a first-order relationship with $\mathrm{VC}$ concentration over a range of 0 to $5 \mathrm{mg} \mathrm{VC/L}$. This first-order relationship would predict much lower continuous-flow VC degradation rates at the operating VC concentrations employed in the continuous-flow runs than were actually observed. Further studies are needed to clarify the large differences between kinetics under semibatch and continuous-flow operations. Continuous-flow kinetics represent a better approximation of VC degradation for a practical treatment system that would presumably operate continuously. However, these data suggest that some process modification might achieve more rapid removals, such as sequencing semibatch operation.

The $\mathrm{VC}$ degradation rates observed during semibatch runs were similar to those reported previously by Fogel et al. (1987) for VC degradation by a suspended methanotrophic consortium. These researchers reported a degradation rate of $14.6 \mathrm{nmol} /(\mathrm{mg} \mathrm{h})[22 \mathrm{mg} /(\mathrm{g} \mathrm{d})]$ at a concentration of 1 to $2 \mathrm{mg} \mathrm{VC/L}$. This reported rate is similar to rates observed during semibatch runs in the present study. It is encouraging that VC degradation rates reported for laboratory microcosms could be maintained in a bioreactor.

Two important limitations of methanotrophic VC degradation were identified during the course of these experiments. The first is the inhibitory or toxic effect of VC on the methanotrophs, and the second is methane inhibition of methanotrophic VC degradation. Continuous exposure of the attached biomass to $\mathrm{VC}$ concentrations of 5 to $10 \mathrm{mg} / \mathrm{L}$, at VC loading rates of $60 \mathrm{mg} \mathrm{VC} /\left(\mathrm{L}_{e b} \mathrm{~d}\right)$, severely limited the metabolism of both methane and VC. However, since the MAFEB reactor operates as a completely mixed system, VC toxicity should not cause system failure as long as conditions are maintained in the reactor that continually support $\mathrm{VC}$ degradation so that effluent VC concentrations are kept below $5 \mathrm{mg} / \mathrm{L}$. However, it is also 
possible that toxic intermediates formed during methanotrophic VC degradation result in cell death proportional to the amount of $\mathrm{VC}$ degraded. Other researchers have suggested that this is the case for TCE degradation, and the amount of TCE degraded per amount of cells killed was termed the "transformation capacity" (Alvarez-Cohen and McCarty 1991). Other researchers reported on the same phenomenon and defined an "inactivation constant," which is the amount of cells killed per amount of VC degraded (Oldenhuis et al. 1991). If this is the case for VC degradation, then loading rates must be maintained in accordance with growth rate to avoid system failure.

The second factor, methane inhibition, was found to limit VC degradation when the dissolved methane concentration in the reactor was above 0.5 $\mathrm{mg} / \mathrm{L}$. Methane inhibition was avoided in continuous-flow runs by reducing the methane gas recycle rate to maintain low partial pressures of methane in the diffuser headspaces. This adjustment may prove more difficult with a full-scale system, and in that case alternative strategies would be required for maintaining low dissolved methane concentrations. An example of such a strategy would be to employ a sequencing semibatch treatment system in which VC and methane feeds are alternately pulsed to the reactor system. Preliminary experiments have indicated that the expanded-bed system continues to degrade $\mathrm{VC}$ for at least $6 \mathrm{~h}$ after eliminating the methane supply. Operation in this mode would allow VC degradation to be executed in the absence of inhibiting methane. After several hours in this mode, the MAFEB system would be rejuvenated with methane off-line.

\section{ACKNOWLEDGMENTS}

This research was supported by the Gas Research Institute under Contract \#5089-260-1798, T. D. Hayes, Project Manager. The writers are very thankful for the assistance of Sean R. Carter, Shawn L. Carter, Donna E. Fennell, Timothy D. Nock, Thomas E. White, and Mark S. Wilson.

\section{APPENDIX. REFERENCES}

Alvarez-Cohen, L., and McCarty, P. L. (1991). "Effects of toxicity, aeration, and reductant supply on trichloroethylene transformation by a mixed methanotrophic culture." Appl. Envir. Microbiol., 57(1), 228-235.

"Ambient water quality criteria for vinyl chloride." (1980). EPA/440/5-80/029, U.S. Environmental Protection Agency, Washington, D.C.

Barrio-Lage, G. A., Parsons, F. Z., Narbaitz, R. M., Lorenzo, P. A., and Archer, H. E. (1990). "Enhanced anerobic biodegradation of vinyl chloride in ground water." Environ. Toxicology. and Chem., 9, 403-415.

Brusseau, G. A., Tsien, H-C., Hanson, R. S., and Wackett, L. P. (1990). "Optimization of trichloroethylene oxidation by methanotrophs and the use of a colorimetric assay to detect soluble methane monooxygenase activity." Biodegradation, 1, 19-29.

Carter, S. R. (1991). "Low temperature biodegradation of tetrachloroethylene in an anaerobic attached film process," M.S. thesis, Cornell Univ., Ithaca, N.Y.

Chaudhry, G. R., and Chapalamadugu, S. (1991). "Biodegradation of halogenated organic compounds." Microbiological Reviews, 55(1), 59-79.

Chu, K-H. (1991). "Treatment of tetrachloroethylene and trichloroethylene with an anaerobic attached film process," M.S. thesis, Cornell Univ., Ithaca, N.Y.

Clarkson, W. W. (1986). "Fermentation of particulate organic matter to methane in a thermophillic anaerobic attached film expanded bed reactor," $\mathrm{PhD}$ thesis, Cornell Univ., Ithaca, N.Y.

Craun, G. F. (1984). "Health aspects of ground water pollution." Ground water 
pollution microbiology, G. Bitton and C. P. Gerba, eds., John Wiley and Sons, New York, N.Y.

Davis, J. W., and Carpenter, C. L. (1990). "Aerobic biodegradation of vinyl chloride in ground water samples." Appl. Environ. Microbiol. 56(12), 3878-3880.

Dooley-Danna, M., Fogel, S., and Findlay, M. (1989). "The sequential anaerobic/ aerobic biodegradation of chlorinated ethenes in an aquifer simulator." Proc., 1989 ASM Meeting. American Society of Microbiology.

Fathepure, B. Z., Nengu, J. P., and Boyd, S. A. (1987). "Anaerobic bacteria that declorinate perchloroethene." Appl. Environ. Microbiol. 53(11), 2671-2674.

Fennell, D. E., Underhill, S. E., and Jewell, W. J. (1992). "Methanotrophic attached-film expanded-bed reactor: system development and biofilm characteristics." Biotechnol. and Bioengrg. , 40(11), 1218-1232.

Fogel, M. M., Taddeo, A. R., and Fogel, S. (1986). "Biodegradation of chlorinated ethenes by a methane-utilizing mixed culture."J. Appl. Environ. Microbiol., 51(4), $720-724$.

Fogel, S. (1990). "Sequential anaerobic/aerobic biodegradation of chlorinated ethenes." Proc., 199th ACS Meeting, Div. of Environ. Chem., American Chemical Society, Washington, D.C.

Fogel, S., Findlay, M., Moore, A., and Leahy, M. (1987). "Biodegradation of chlorinated chemicals in ground water by methane oxidizing bacteria." Nat. Water Well Assn. Conf. on Petroleum Hydrocarbons and Organic Chemicals in Ground Water: Prevention, Detection and Restoration.

Freedman, D. L., and Gossett. J. M. (1989). "Biological reductive dechlorination of tetrachloroethylene and trichloroethylene to ethylene under methanogenic conditions." Appl. Environ. Microbiol., 55(9), 2144-2151.

Gossett, J. M. (1987). "Measurement of Henry's law constants for C1 and C2 chlorinated hydrocarbons." Envir. Sci. and Tech., 21, 202-208.

Hartmans, S., de Bont. J. A. M., Tramper, J.. and Luyben, K. Ch. A. M. (1985). "Bacterial degradation of vinyl chloride." Biotech. Letters, 7(6), 383-388.

Henry, S. M., and Grbic-Galic, D. (1991). "Inhibition of trichloroethylene oxidation by the transformation intermediate carbon monoxide." Appl. Environ. Microbiol., $57(6), 1770-1776$.

Infante, P. F., and Tsongas, T. A. (1982). "Mutagenic and oncogenic effects of chloromethanes, chloroethanes and halogenated analogues of vinyl chloride." Envir. Sci. Res., 25, 301-327.

Jewell, W. J., Fennell, D. E., Nelson, Y. M., Underhill, S. E., White, T. E., and Wilson. M. S. (1990). "Methanotrophs and methanogens for pollution control: PCE and TCE removal from ground water and macro nutrient removals from wastewater." Res. Rep., Gas Research Institute and Radian Corp.. Chicago, Ill.

Leak, D. J., and Dalton, H. (1986). "Growth yields of methanotrophs: 1. effect of copper on the energetics of methane oxidation." Appl. Microbiol. Biotechnol., $23,470-476$.

Lee, C. C., Bhandari, J. C., Winston, J. M., House, W. B., Dixon, R. L., and Woods, J. S. (1978). "Carcinogenicity of vinyl chloride and vinylidene chloride." J. Toxic. Envir. Health, 4, 15-30.

Love, O. T., and Eilers, R. G. (1982). "Treatment of drinking water containing trichloroethylene and related industrial solvents." J. Amer. Water Works Assn., $74,413-425$.

Maltoni, C. (1977). "Vinyl chloride carcinogenicity: an experimental model for carcinogenicity studies." Origins of human cancer. H. H. Hiatt, J. D. Watson, and J. A. Winsten, eds., Cold Spring Harbor, N.Y., 119-146

Milde, G., Nerger, M., and Mergler, R. (1988). "Biological degradation of volatile chlorinated hydrocarbons in ground water." Water Sci. Technol., 20(3), 67-73.

Molton, P. M., Hallen, R. T., and Pyne, J. W. (1987). "Study of vinyl chloride formation at landfill sites in California." $B N W L-2311206978$, Batelle Pacific Northwest Laboratories, Richland, Wash.

Oldenhuis, R., Oedzes, J. Y., van der Waarde, J. J., and Janssen, D. B. (1991). "Kinetics of chlorinated hydrocarbon degradation by methylosinus trichosporium OB3b and toxicity of trichloroethylene." Appl. Environ. Microbiol., 57(1), 7-14. 
Parsons, F., Barrio-Lage, G., and Rice, R. (1985). "Biotransformation of chlorinated organic solvents in static microcosms." Environ. Toxic. Chem., 4, 739-742.

Parsons, F., Wood, P. R., and DeMarco, J. (1984). "Transformations of tetrachloroethylene and trichloroethylene in microcosms and ground water." J. Amer. Waterworks Assn., 76, 56-59.

Roberts, P. V., Simprini, L.. Hopkins, G. D., Grbic-Galic, D., McCarty, P. L., and Reinhard, M. (1989). "In-situ aquifer restoration of chlorinated aliphatics by methanotrophic bacteria." U.S. EPA Rep. \#600/2-89/033, U.S. Environmental Protection Agency, Washington, D.C.

Standard methods for the examination of water and wastewater. (1985). 16th Ed., Am. Pub. Health Assn., Am. Water Works Assn., Water Poll. Contr. Fed., Washington, D.C.

Tsien, H.-C., Brusseau, G. A., Hanson, R. S., and Wacket, L. P. (1989). "Biodegradation of trichloroethylene by methylosinus trichosporium OB3b." Appl. Environ. Microbiol., 55(12), 3155-3161.

Vary, P. S., and Johnson, M. J. (1967). "Cell yield of bacteria grown on methane." Appl. Microbiol., 15(6), 1473-1478.

Vogel, T. M. , and McCarty, P. L. (1985). "Biotransformation of tetrachloroethylene to trichloroethylene, dichloroethylene, vinyl chloride and carbon dioxide under methanogenic conditions." Appl. Environ. Microbiol., 49(5), 1080-1083.

Vogel, T. M., Criddle, C. S., and McCarty, P. L. (1987). "Transformations of halogenated aliphatic compounds." Environ. Sci. Technol., 21(8), 722--736.

Westrick, J. J., Mello, J. W., and Thomas, R. F. (1984). "The ground water supply survey." J. Amer. Water Works Assoc., 76, 52-59. 